\title{
EFEKTIVITAS SPIRITUAL EMOTIONAL FREEDOM TECHNIQUE (SEFT) DALAM MEREDUKSI EMOSI MARAH SISWA DI MADRASAH TSANAWIYAH MUHAMMADIYAH GEDONGTENGEN
}

\author{
Anang Sumarna \\ Program Pasca Sarjana Magister Studi Islam \\ Universitas Muhammadiyah Yogyakarta \\ E-mail: anangsumarna@yahoo.com
}

\begin{abstract}
Abstrak
Penelitian ini bertujuan untuk: (1) mengetahui kemampuan pengendalian emosi marah pada siswa MTs Muhammadiyah Gedongtengen Kota Yogyakarta; (2) mengukur efektivitas Spiritual Emotional Freedom Technique (SEFT) dalam mereduksi emosi marah siswa di MTs Muhammadiyah Gedongtengen; (3) mendeskripsikan penerapan Spiritual Emotional Freedom Technique (SEFT) dalam pembelajaran siswa di MTs Muhammadiyah Gedongtengen. Jenis penelitian adalah penelitian kualitatif. Adapun lokasi yang dipilih oleh peneliti adalah Madrasah Tsanawiyah Muhammadiyah Gedongtengen Kota Yogyakarta. Metode pengumpulan data yaitu wawancara mendalam dan dokumentasi. Hasil penelitian ini (1) kemampuan pengendalian emosi marah pada siswa MTs Muhammadiyah Gedongtengen Kota Yogyakarta masih tergolong rendah; (2) desain dan penerapan Spiritual Emotional Freedom Technique (SEFT) dalam pembelajaran siswa di MTs Muhammadiyah Gedongtengen Kota Yogyakarta dapat dilakukan dengan cara pengembangan Rencana Pelaksanaan Pembelajaran (RPP) yang menunjang aspek spiritual, walaupun hanya nurturant efect, bukan instructional efect; (3) Spiritual Emotional Freedom Technique (SEFT) dalam mereduksi emosi marah siswa secara klasikal di MTs Muhammadiyah Gedongtengen tidak efektif.
\end{abstract}

Kata kunci: efektifitas, spiritual emotional freedom technique, emosi marah

\begin{abstract}
This study aims to: (1) know the emotional control ability of angry at students MTs Muhammadiyah Gedongtengen Yogyakarta; (2) to measure the effectiveness of Spiritual Emotional Freedom Technique (SEFT) in reducing the anger of students at MTs Muhammadiyah Gedongtengen; (3) to describe the application of Spiritual Emotional Freedom Technique (SEFT) in student learning at MTs Muhammadiyah Gedongtengen. The type of research is qualitative research. The location chosen by the researcher is Madrasah Tsanawiyah Muhammadiyah Gedongtengen Yogyakarta. Methods of data collection are in-depth interviews and documentation. The results of this study (1) emotional control ability angry at students MTs Muhammadiyah Gedongtengen Yogyakarta is still relatively low; (2) the design and application of Spiritual Emotional Freedom Technique (SEFT) in student learning at MTs Muhammadiyah Gedongtengen Yogyakarta City can be done by developing Learning Plan (RPP) that support spiritual aspect, although only nurturant efect, not instructional efect; (3) Spiritual Emotional Freedom Technique (SEFT) in reducing students' angry emotion classically in MTs Muhammadiyah Gedongtengen is not effective.

Keywords: effectiveness, spiritual emotional freedom technique, angry emotion
\end{abstract}

\section{Info Artikel}

Diterima Januari 2018, disetujui Februari 2018, diterbitkan Juni 2018

Dipublikasikan Oleh: Program Studi Bimbingan dan Konseling 


\section{PENDAHULUAN}

Sekolah yang berkualitas akan mampu mencetak output yang berkualitas. Ukuran kualitas lulusan tidak hanya diukur dari kematangan kognitif saja, akan tetapi matang juga secara emosional, sosial, dapat menyesuaikan diri dengan lingkungan, dapat mengembangkan bakat yang ada dalam dirinya, dapat memenuhi kebutuhannya secara mandiri dan juga kematangan moral. Siswa berkualitas akan memiliki moral yang baik, baik yang berlandaskan kepada normanorma yang berlaku dalam masyarakat maupun moral yang ada dalam agama.

Kualitas siswa dalam konteks kematangan emosional, pada dasarnya tidak dapat dipisahkan dari kualitas layanan pengelolaan emosinya, baik dalam layanan bimbingan dan konseling maupun pengelolaan emosi oleh guru di luar layanan bimbingan konseling. Siswa pada galibnya tergolong usia remaja, antara 12 sampai dengan 15 tahun, emosi mereka cenderung labil. Mereka mengalami gejolak emosi dan tekanan jiwa sehingga mudah menyimpang dari aturan dan norma-norma sosial.

Siswa Madrasah Tsanawiyah Muhammadiyah Gedongtengen Kota Yogyakarta merupakan dari sekian siswa yang rentan dengan gangguan emosi karena erat hubungannya dengan keadaan hormon. Suatu saat ia bisa mengalami perasaan yang sangat sedih, di lain waktu ia bisa marah sekali. Emosi mereka lebih kuat dan menguasai dirinya daripada pikiran yang realistis. Akibat dari gangguan emosi, mereka berperilaku menyimpang atau melanggat tata tertib madrasah. Hal ini tentu mengakibatkan beban berat bagi keluarga dan sekolah.

Dalam melakukan pelanggaran, siswa dapat dilihat dari dua perspektif, yaitu: (1) siswa sebagai pelaku, dan (2) siswa sebagai korban. Hal yang sering dilihat dari siswa ketika melakukan pelanggaran (deliquences) adalah dia semata-mata sebagai pelaku. Ini tidaklah adil, karena banyak hal yang harus diungkap sebagai penyebab psikologis siswa yang mengakibatkan berprilaku menyimpang.

Dalam mengoptimalkan pengelolaan emosi, siswa harus dipandang secara holistic. Mereka sebagai individu yang berjiwa raga. Penerapan punishment yang berkelanjutan diasumsikan akan memiliki implikasi pada gangguan fisik maupun psikis. Gangguan fisik dapat muncul seperti lelah, sakit fisik, bahkan cacat secara fisik. Di Majalengka, Lintang siswi SMP 1 Palasah, Kecamatan Palasah, Kabupaten Majalengka, meninggal di sekolahnya sekitar pukul 11.00 WIB setelah jatuh pingsan. Korban jatuh pingsan ketika sedang menjalani hukuman bersama 14 siswa lainnya dari guru Bahasa Indonesia, karena tidak mengerjakan Pekerjaan Rumah (PR).

Di lain tempat, Tiffani seorang siswi Sekolah Menengah Pertama 
(SMP) terjatuh dari lantai dua gedung sekolah HKBP Pardamean, di Jalan Taduan, Kecamatan Medan Tembung. Siswi tersebut dihukum gurunya membersihkan kaca jendela kelas, karena telat masuk sekolah. Kasus dalam konteks ini pada dasarnya untuk mencapai penegakkan kedisiplinan siswa. Hukuman yang diberikan dalam konteks ini biasanya dikenal dengan corporal punishment; hukuman kedisiplinan.

Adapun gangguan psikis dapat muncul berupa emosi negative seperti frustasi, takut, marah, benci, dan lain sebagainya. Berpijak dari fakta tersebut, sudah semestinya ada perubahan paradigma dalam penegakkan hukuman. Dari punishment menuju therapy adalah refleksi signifikan dalam konteks ini, karena tindak pelanggarana siswa dapat berawal dari gangguan emosi siswa.

Di MTs Muhammadiyah Gedongtengen Kota Yogyakarta, emosi negatif siswa pada saat-saat tertentu muncul. Marah pada guru maupun marah kepada orang tua mereka merupakan salah satu contoh dari emosi negatif. Penanganan masih berorientasi kepada corporal punishment. Orientasinya lebih mengarah kepada sikap jera siswa agar tidak mengulangi pelanggaran. Hal ini dapat dilihat dari jenis point pelanggaran (point punishment) yang diberlakukan, cara berkomunkasi, sikap guru BK dan guru lainnya terhadap siswa. Dalam hal ini pun belum ditemukan program terapi maupun point reward untuk siswa secara terstruktur.

Idealnya,

penegakkan punishment tidak mengakibatkan efek negatif baik secara fisik maupun psikis siswa. Dalam hal ini, madrasah dapat merubah bentuk penanganan pelanggaran siswa dari punishment menuju terapi. Secara teori dalam penanganan bentuk-bentuk pelanggaran siswa sudah ada pendekatan-pendekatan terapi, seperti terapi perilaku (behavior therapy) dan pengubahan perilaku (behavior modification) atau pendekatan perilaku dalam konseling dan psikoterapi, yang merupakan satu dari beberapa revolusi dalam dunia pengetahuan psikologi, khususnya konseling dan psikoterapi. Dengan demikian, sudah ada teori untuk mengubah paradigma punishment menuju terapi.

Dewasa ini, ada salah satu metode terapi untuk mengantisipasi gangguan emosi. Emotional Freedom Technique merupakan metode yang dimaksud. Metode ini dikembangkan lebih lanjut menjadi Spiritual Emotional Freedom Techniq (SEFT). Oleh karena itu dipandang perlu untuk meneliti efektivitas SEFT dalam mereduksi gangguan emosi siswa, khususnya emosi marah. Dengan demikian, punishment yang selama ini menjadi orientasi dalam corporal punishment dapat diubah secara terstruktur ke arah terapi. 
Di MTs Muhammadiyah GedongtengenKota Yogyakarta, sudah ada sebagain guru yang mengenal teknik SEFT ini. Di antaranya adalah guru PAI dan Guru BK. Secara teori, karena SEFT ini bukan satu-satunya teknik baru dalam mereduksi emosi negatif, maka informasi tentangnya sudah banyak yang mengetahui. Hanya saja, penggunaannya lebih diterapkan pada terapi atau pengobatan dalam bidang medis dan psikoterapi oleh para ahli di luar bidang pendidikan. Oleh karena itu, penggunaan dan efektifitasnya perlu diujicobaka dalam bidang pendidikan.

Penggunaan SEFT yang sudah pernah digunakan di MTs Muhammadiyah Gedongtengen Kota Yogyakarta adalah teknik SEFT yang mengiringi kegiatan AMT (Achievement and Motivation Training) menjelang Ujian Nasional. Belum ada penelitian efektif atau tidaknya teknik tersebut di MTs Muhammadiyah Gedongtengen Kota Yogyakarta. Dapat dikatakan bahwa teknik SEFT di MTs tersebut tidak diterapkan secara serius, sifatnya insidental tanpa program. Dengan demikian, perlu diadakan satu penelitian tentang "Efektifitas SEFT untuk Mereduksi Emosi Marah Siswa di MTs Muhammadiyah Gedongtengen".

\section{METODE PENELITIAN}

Jenis penelitian ini menggunakan deskriptif kualitatif. Hal ini bertujuan untuk menjelaskan fenomena yang mendalam melalui pengumpulan data sebanyakbanyaknya. Spesifikasi penelitian yang digunakan adalah deskriptif analisis yang bertujuan untuk membuat deskripsi atau gambaran mengenai fakta-fakta, sifat-sifat serta hubungan antara fenomena yang diselidiki. Penelitian deskriptif ini merupakan penelitian yang tidak dimaksudkan untuk menguji hipotesis tertentu tetapi hanya menggambarkan apa adanya tentang sesuatu variabel, gejala atau keadaan.

Populasi dalam penelitian ini adalah siswa MTs Muhammadiyah Gedongtengen Kota Yogyakarta pada tahun pelajaran 2016/2017 yang dijadikan sumber informasi yang dibutuhkan dalam pengumpulan data penelitian. Dalam penelitian ini mereka berperan sebagai informan, yaitu orang yang memberi informasi tentang data yang diinginkan peneliti berkaitang dengan penelitian yang sedang dilaksanakan. Sampel yang diambil dari keseluruhan populasi adalah 30 siswa. Mengingat adanya strata subjek penelitian yang terdiri dari kelas VII, VIII, dan IX, maka teknik pengambilan sampel yang digunakan dalam penelitian ini adalah purposive sampling. Peneliti menentuakn sendiri sampel yang diambil karena pertimbangan tertentu.

Dengan demikian, sampel penelitian tidak diambil secara acak. Pemilihan teknik penentuan sampel seprerti itu, karena subjek penelitian diseleksi atas dasar kriteria-kriteria 
tertentu berdasarkan tujuan penelitian. Di antara kriteria tersebut adalah siswa MTs Muhammadiyah Gedongtengen dengan krteria: (1) siswa yang sudah pernah masuk dalam catatan kasus BK, (2) siswa yang pernah berkelahi di madrasah, (3) siswa yang intensitas marahnya lebih dominan dibanding siswa lain, (4) siswa yang punya karakter keras, (5) siswa pendiam dan dikucilkan.

Siswa yang pernah masuk catatan BK terdiri dari seluruh sampel. Siswa yang sudah pernah berkelahi di madrasah ada 6 orang. Siswa yang intensitas marahnya lebih dominan dibanding siswa lainnya ada 2 orang. Siswa yang memiliki karakter keras ada 4 orang. Adapun siswa yang pendiam dan cenderung dikucilkan ada 1 orang. Jumlah ini tidak bisa dipisahkan antara satu kriteria dengan kriteria lainnya, karena ada beberapa orang yang memenuhi lebih dari satu kriteria. Peneliti mengambil sampel dari setiap kelas sebanyak $20 \%$ sehingga diperoleh sampel sebanyak 30 orang. Dari 30 orang inilah yang akan menjadi responden mewakili siswa MTs Muhammadiyah Gedongtengen Kota Yogyakarta.

Adapun langkah-langkah penelitian yang dilakukan adalah sebagai berikut:

1. Persiapan

a. Peneliti memilih siswa dari rekomendasi dan catatan $\mathrm{BK}$

b. Peneliti melakukan konfirmasi dengan mewawancarai subjek, wawancara dengan guru, dan orang tua.

c. Peneliti mengarahkan kesadaran siswa dari sikap yang dimiliki untuk sadar rasa dan sadar peristiwa.

d. Peneliti mengambil kesepakatan subjek penelitian untuk menerima pelatihan teknik SEFT.

e. Pemilihan tempat yang nyaman untuk terapi SEFT. Tempat yang dipilih adalah ruang lab madrasah yang kondisinya luas dan tidak terlalu ramai dengan suara siswa lain.

f. Bantuan Terapis (Sefter). Dalam hal ini peneliti bertindak sebagai sefter dibantu oleh seorang terapis (Sefter)

2. Pelaksanaan

a. Menata hati subjek penelitian untuk menghadirkan rasa yakin terhadap Maha Kuasanya Allah SWT; bahwa jika Allah turun tangan, maka tidak ada yang mustahil dan jika Allah tidak berkehendak, maka tidak ada yang bisa dicapai. Masih dalam menata hati subjek, peneliti memberikan stimulus untuk menghadirkan perasaan khusyu, ikhlas, pasrah, dan syukur.

b. Melakukan Set Up

Dalam tahapan ini, peneliti mengklarifikasi masalah marah yang dirasakan dan 
intensitasnya. Masih dalam set up, peneliti membimbing subjek untuk minum air putih, menghadirkan rasa cinta dan syukur dengan mengucap basmalah dan hamdalah, menekan sore spot dan mengucapkan kalimat set up.

b. Melakukan Tune In

Dalam tahap ini, peneliti membimbing subjek untuk menghadirkan peristiwa yang dapat membangkitkan emosi marah yang dimaksud. Kemudian ketika perasaan marah sudah terbangun kembali, lisan dan hati subjek dibimbing untuk menerima dan memasrahkan perasaan itu kepada Allah SWT.

c. Melakukan Tapping

Dalam tahap ini, tune in tetap dipertahankan. Sambil terusmenerus melakukan tune in, mulai dilakukan tapping; mengetuk ringan dengan dua ujung jari telunjuk dan jari tengah pada titik-titik kunci dari The Major Energy Meridians dengan jumlah titik 9 dalam versi singkat. Setiap selesai satu putaran tapping, selalu diakhiri dengan menarik nafas panjang dan mengucapkan syukur alhamdulillah.

d. Melakukan Nine Gamut Procedure

Dalam langkah ini dilakukan EMDR; Eye Movement
Desensitization Reprocessing. Subjek dibimbing untuk menutup mata secara kuat, membuka mata lebar-lebar, melirik ke arah kanan dan kiri bawah, memutar bola mata dan bergumam dengan irama selama tiga detik.

3. Refleksi, Observasi, wawancara, dan Interpretasi

Setelah melakukan tindakan, diadakan refleksi dengan subjek penelitian, dikonfirmasi tentang intensitas emosi negatifnya. Lebih lanjut dari itu, peneliti melakukan observasi dalam pekan setelah dilakukan tindakan, melakukan wawancara dengan subjek, dengan guru BK, guru madrasah, orang tua siswa, dan teman-teman subjek.

4. Evaluasi SEFT

Hasil dari kuisoner posttest, observasi, dan wawancara dianalisis dan diinterpretasikan untuk mengetahui efektifitas SEFT dalam mereduksi emosi marah siswa. Menguji tingkat keberhasilan SEFT dikembalikan lagi kepada subjek dan hasil observasi lanjutan. Hal yang dievaluasi dalam tahap ini adalah intensitas emosi, reduksi emosi, dan tingkat kekuatan spiritualnya seperti yakin, khusyu, ikhlas, pasrah, dan syukur. Untuk mengantisipasi rendahnya tingkat keberhasilan SEFT, peneliti menyiapkan setting Personal Peace Procedure untuk membantu 
mereduksi emosi marah yang perlu mereka SEFTing agar perasaan lebih tenang, prestasi lebih baik, dan hidup lebih bermakna.

\section{HASIL PENELITIAN DAN PEMBAHASAN}

Terapi SEFT yang diterapkan untuk subjek penelitian, merupakan intervensi dalam mereduksi emosi marah siswa. Hasil dari bimbingan SEFT yang sudah dilakukan adalah sebagai berikut:

1. SEFT Secara Kelompok

SEFT yang diterapkan pada siswa MTs Muhammadiyah Gedongtengen Kota Yogyakarta, ada yang diterapkan secara klasikal dari keseluruhan sampel yang diteliti.

Tabel 1.

Hasil Terapi SEFT Kelompok

\begin{tabular}{|l|c|c|c|}
\hline No. & $\begin{array}{c}\text { Efek } \\
\text { Tindakan } \\
\text { SEFT }\end{array}$ & Frekuensi & Keterangan \\
\hline 1. & Menurun & 17 & Kelompok \\
\hline 2. & $\begin{array}{c}\text { Tidak ada } \\
\text { efek }\end{array}$ & 13 & Kelompok \\
\hline
\end{tabular}

Hasil dari penggunaan SEFT dalam tabel di atas menunjukkan 56,6 $\%$ yang merasakan penurunan emosi marah yang mereka rasakan. Adapun 43,4 \% siswa tidak merasakan efek dari SEFT. Angka-angka tersebut telah menjawab satu pertanyaan tentang level berapa mereka merasakan emosi amarah yang dimiliki sebagai rasa dendam kepada orang lain.

2. SEFT Secara Individual

Individu yang dimaksud adalah subjek yang memiliki emosi marah lebih besar dari subjek yang lain. Hal ini terungkap dari kasus perkelahian atau adu mulut antara dirinya dengan temannya di madrasah. Pada penerapan SEFT untuk mereduksi marah secara individual, lebih dirasakan keseriusannya karena mereka tidak saling mempengaruhi dan tidak menganggap main-main lagi. Ada dua subjek yang dijadikan sampel dalam SEFT secara individual ini. Hasilnya dapat dilihat dalam tabel berikut:

Tabel 2.

Hasil Terapi SEFT Individu

\begin{tabular}{|c|c|c|c|}
\hline No. & Subjek & $\begin{array}{c}\text { Level } \\
\text { Awal }\end{array}$ & Hasil \\
\hline 1. & A1 & 3 & Menurun \\
\hline 2. & A2 & 4 & Menurun \\
\hline
\end{tabular}

Dari tabel di atas tampak bahwa A1 sejak sebelum merasakan SEFT secara individual, sudah merasakan penurunan emosi marah dibandingkan pada saat ia sebelum menerima SEFT dalam kelompok atau kelas. Pada akhirnya, emosi marah sudah menurun di level satu. Begitu halnya dengan subjek A2 yang merasakan penurunan emosi marah dengan intensitas emosi yang lebih rendah dibandingkan 
dengan sebelum ia menerima SEFT. Walaupun semuanya memiliki kelabilan emosi yang berbeda dari waktu ke waktu, apabila dilihat dari hasil akhirnya mendapatkan angka $100 \%$ tentang penurunan emosi marah yang tinggi dari semua sampel penelitian.

Level emosi marah yang dijadikan ukuran adalah level 1 samapi level 10. Tingkat emosi marah yang ringan berada dalam kisaran level 1 sampai dengan 3. Tingkat emosi marah level sedang berada dalam kisaran level 4 sampai dengan level 7. Adapun level berat berada di level 8 sampai 10 .

Penelitian yang dilakukan dapat berhasil dalam penerapan SEFT secara individual. Hal ini didukung dengan adanya faktor sebagai berikut:

a. Kebutuhan Penanganan Masalah Siswa Secara Spiritual

Kondisi emosi siswa di madrasah tersebut beraneka ragam, seperti marah, sedih, takut setelah menerima hukuman, dan lain sebagainya. Pada dasarnya mereka memiliki tumpukan emosi-emosi negatif yang dirasakan dari masa lalunya. Kondisi seperti ini butuh penanganan kasus secara spiritual yang berorientasi pada pelepasan emosi negatif, khususnya emosi marah. Kebutuhan ini menjadi pendukung diterapkannya teknik SEFT. b. SEFT Mudah dipelajari dan diterapkan

Menurut para narasumber yang sudah berpengalaman menjelaskan bahwa SEFT tidak memerlukan background pendidikan tertentu. Ia lebih mengarah pada stimulasi pada posisi pasrah dan yakin akan keberadaan dan pertolongan Allah SWT. Siswa di MTs Muhammadiyah Gedongtengen Kota Yogyakarta sudah mampu untuk men-set up, tune in, dan tapping. Artinya, tidak menghadapi banyak kesulitan dalam menggunakannya.

c. Layanan BK

Faktor pendukung lainnya adalah layanan Bimbingan Konseling (BK) di madrasah. Guru BK biasanya menjadi bagian dari jabatan fungsional di madrasah yang ditakuti siswa, karena BK lah yang biasanya memanggil siswasiswa yang bermasalah. Pola pikir siswa masih menganggap bahwa siswa yang dipanggil oleh $\mathrm{BK}$ adalah siswa yang bermasalah. Akan tetapi, layanan BK pada dasanya untuk mengoptimalkan juga potensi yang ada dalam dirinya.

d. Kegiatan AMT

Di MTs Muhammadiyah Gedongtengen, kegiatan training motivasi dan prestasi selalu diadakan setahun sekali, khusus untuk siswa kelas IX menjelang ujian akhir atau ujian nasional. Materi-materi yang disampaikan 
tidak lepas dari bagaimana siswa memiliki kesehatan mental, tenang, yakin, pasrah atas pertolongan Allah SWT. Bahkan pernah sesekali kegiatan AMT di madrasah tersebut menyisipkan teknik SEFT dalam kegiatan AMT.

e. Penanganan kasus secar spiritual Kasus-kasus pribadi siswa di MTs Muhammadiyah Gedongtengen tidak hanya diselesaikan dengan bobot point pelanggaran dalam konteks punishment, akan tetapi digunakan juga pendekatan spiritual. Dalam kasus siswa marah atau beradu fisik dan perang mulut dengan temannya, maka sudah pernah dilakukan peredaman emosi dengan cara berwudhu. Seperti halnya subjek A1 yang menjadi sampel penelitian ini, pernah diredam emosinya dengan cara dibimbing melakukan wudhu.

Akan tetapi, keberhasilan tersebut bukan berarti tanpa faktor penghambat. Hambatan-hambatan yang terjadi, ada yang sifatnya dapat diprediksi, tetapi ada juga yang terjadi secara alamiah dan spontan terjadi. Beberapa subjek yang dijadikan sampel dalam penelitian ini tampak tidak serius mengikuti training SEFT. Mereka banyak yang menganggap teknik ini aneh dan lucu. Ketidakseriusan tersebut terjadi terutama ketika SEFT diberikan dalam sistem kelompok.
Di samping subjek tidak serius, terjadi juga penolakan-penolakan. Sebagian subjek merasa ketakutan untuk mendapatkan perlakuan atau intervensi. Hal ini mengakibatkan mereka tidak sepenuh hati untuk menjalankan instruksi-instruksi dari peneliti. Hambatan lainnya, penghayatan subjek yang sangat lemah. Penghayatan terhadap apa yang mereka ucapkan seharusnya menjadi pendukung keberhasilan dalam tahap set up dan tune in. Penghayatan ini masalah hati subjek yang belum mengizinkan untuk menerima emosi marah dan melepaskannya sejauh mungkin. Ruangan yang tidak kondusif juga menjadi penghambat keberhasilan SEFT. Di samping tidak kedap suara, jendela ruangan juga terlalu bawah, sehingga siswa lain dapat menonton apa yang sedang terjadi. Akibatnya sebagian subjek menjadi tidak konsentrasi dan tidak serius.

Hambatan lainnya adalah SEFTER yang berprofesi sebagai guru jarang ditemui. Di saat-saat pelatihan, rata-rata alumni SEFT yang ditemui berprofesi dalam bisnis dan kesehatan atau akupuntur. Karena memang salah satu tujuan dari SEFT adalah meraih magnet-magnet kesuksesan dan juga penyembuhan. Buku SEFT juga tidak bebas dijual. Tidak mudah menemukan buku SEFT di lapangan. Biasany buku tersebut hanya dimiliki oleh alumni-alumni atau SEFTER yang sudah menjadi trainer atau stokis. Hal ini menjadi kendala bagi 
siapa yang akan mendalami SEFT. Termasuk guru BK juga belum memiliki buku tersebut.

Faktor penghambat lainnya, Tidak ada alokasi waktu dan program khusus. Alokasi waktu dalam penanganan kasus pribadi siswa yang memiliki emosi marah tidak diposisikan secara khusus. Pendekatan guru BK dalam meredam atau mereduksi emosi marah lebih mengarah kepada punishment atau hukuman. Siswa akan patuh dan tidak muncul emosi marahnya karena sudah ada unsur takut akan kena hukuman.

Menjawab tentang efektifitas dalam penelitian ini berorientasi pada hasil atau kondisi akhir setelah penelitian. Apabila dikaitkan dengan SEFT, maka efektifitas dalam hal ini bermakna keadaan yang menggambarkan sejauh mana hasil guna yang diperoleh setelah ada perlakuan Spiritual Emotional Freedom Technique terhadap siswa. Adapun indikator efektivitas dalam penelitian ini adalah perubahan intensitas emosi marah. Dari penelitian yang dilakukan menghasilkan data $56,6 \%$ dalam perlakuan SEFT terhadap kelompok dan $100 \%$ terhadap individu dengan intensitas emosi marah yang tinggi.

Rentang yang dipakai mengetahui efektifitas atau tidaknya dari intervensi SEFT dalam mereduksi emosi marah adalah sebagai berikut:
Tabel 3.

Rentang Efektifitas SEFT

\begin{tabular}{|l|c|c|}
\hline No. & Presentase & Kategori \\
\hline 1. & $0-70 \%$ & tidak efektif \\
\hline 2. & $71-80 \%$ & kurang efektif \\
\hline 3. & $81-90 \%$ & cukup efektif \\
\hline 4. & $91-100 \%$ & sangat efektif \\
\hline
\end{tabular}

Dari data penelitian yang diperoleh adalah 56,6 \% untuk perlakuan SEFT terhadap kelompok dan $100 \%$ dari perlakuan SEFT terhadap individu dengan intensitas emosi marah yang tinggi. Hal ini menunjukkan bahwa SEFT untuk mereduksi emosi marah siswa di MTs Muhammadiyah Gedongtengen Kota Yogyakarta tidak efektif dipakai dalam kelompok. Adapun untuk perlakuan SEFT bagi individu yang emosi marahnya tinggi sangat efektif untuk dilakukan.

\section{SIMPULAN}

Dari hasil penelitian tentang efektifitas SEFT dalam mereduksi emosi marah siswa dapat disimpulkan sebagai berikut:

1. Kemampuan pengendalian emosi marah pada siswa MTs Muhammadiyah Gedongtengen Kota Yogyakarta masih tergolong rendah. Mereka masih memiliki kepentingan untuk menunjukkan power individu dengan emosi marah. 
2. Desain dan penerapan Spiritual Emotional Freedom Technique (SEFT) dalam pembelajaran siswa di MTs Muhammadiyah Gedongtengen Kota Yogyakarta dapat dilakukan dengan cara pengembangan Rencana Pelaksanaan Pembelajaran (RPP) yang menunjang aspek spiritual, walaupun hanya nurturant efect, bukan instructional efect. Di samping itu, dalam layanan BK, SEFT diakomodasi dengan metode penanganan kasus-kasus pribadi yang berorientasi ke dalam terapi, bukan semata-mata punishment (hukuman).

3. Spiritual Emotional Freedom Technique (SEFT) dalam mereduksi emosi marah siswa secara klasikal di MTs Muhammadiyah Gedongtengen tidak efektif. Hal ini disebabakan oleh ditemukannya faktor penghambat, seperti ruangan yang tidak kondusif, tidak ada program SEFT dalam penanganan kasus siswa, buku-buku SEFT juga tidak dijual bebas sehingga BK tidak dapat mengakses. Dari data penelitian yang diperoleh adalah $56,6 \%$ untuk perlakuan SEFT terhadap kelompok dan $100 \%$ dari perlakuan SEFT terhadap individu dengan intensitas emosi marah yang tinggi. Hal ini menunjukkan bahwa SEFT untuk mereduksi emosi marah siswa di MTs Muhammadiyah Gedongtengen Kota Yogyakarta tidak efektif dipakai dalam kelompok. Adapun untuk perlakuan SEFT bagi individu yang emosi marahnya tinggi sangat efektif untuk dilakukan

\section{SARAN}

1. Siswa MTs Muhammadiyah Gedongtengen merupakan siswa yang membutuhkan kasih sayang dan perhatian secara personal. Pendekatan yang digunakanpun sebaiknya secara personal. Mereka tidak menginginkan didikte, dibimbing paksa, ataupun diajar dengan keras dan kasar.

2. Masih ada kesempatan untuk mendesain pembelajaran maupun dalam layanan Bimbingan dan Konseling (BK). Dengan adanya pengembangan SEFT dalam layanan BK, seharusnya penanganan kasus-kasus pribadi lebih mengarah ke dalam terapi, bukan punishment (hukuman).

3. SEFT yang diterapkan di MTs Muhammadiyah Gedongtengen Kota Yogyakarta sebaiknya dilakukan secara individu, bukan SEFT klasikal. Faktor-faktor penghambat harus direduksi untuk menunjang keberhasilan SEFT. Jika mungkin terjangkau, perlu dibuat ruang terapi yang kondusif, di samping ruang layanan BK yang sudah ada. 


\section{DAFTAR PUSTAKA}

Abbas Tashakkori. 2010. Mixed Methodology;

Mengkombinasikan Pendekatan Kuantitatif dan Kuantitatif. Yogyakarta: Pustaka Pelajar.

Ahmad Faiz Zainuudin. 2006. SEFT (Spiritual Emotional Freedom Technique). Jakarta: Arga Publishing.

Anwar, Zainul. 2011. Model Terapi SEFT (Spiritual Emotional Freedom Technique) Untuk Mengatasi Gangguan Fobia Spesifik. Jurnal Psikologi UMM.

Barbara K. Given. 2007. Brain Based Teaching (terj.) Lala Herawati. Bandung: Mizan Media Utama.

Bondan Agus Suryanto. 2015. Terapi Mengendalikan Pikiran dan Hormon dengan Metode RCI. Yogyakarta: Kana Media.

Bradberry dan Graeaves. 2009. Taklukan Emosimu: The Way of Emotional Quotient for Your Better Life. Jogjakarta: Garailmu.

Daniel Goleman. 2015. Emotional Intelligence, mengapa EI lebih penting daripada IQ. Jakarta: Gramedia Pustaka.

Elva Yunita. 2013. Penerapan Spiritual Emotional Freedom Technique Dalam bimbingan Kelompok Untuk Menurunkan Kecemasan Siswa SMA dalam Menghadapi Ujian Nasional. Jurnal BK UNESA Volume 3
No.1. Surabaya: Fakultas Ilmu Pendidikan.

Hamzah B. Uno. 2008. Teori Motivasi dan Pengukuranaya: Analisis Bidang Pendidikan. Jakarta: Bumi Aksara.

Imam Barnadib. 1994. Filsafat Pendidikan. Yogyakarta: Andi Offset

Kusnanto. 2016. Spiritual Emotional Freedom Technique (SEFT) Terhadap Kualitas Hidup Penderita Tuberkolosis Paru. Jurnal Keperawatan Volume 4 No. 3. Surabaya: Universitas Airlangga.

Muhammad Ali. 1987. Penelitian Kependudukan, Prosedur dan strategi, Bandung: Angkasa.

Muhammad Idrus. 2007. Metode Penelitian Ilmu-ilmu Sosial. Yogyakarta: UII Press.

Muthmainnah Zakiyyah. 2013. Pengaruh Terapi Spiritual Emosional Freedom Technique (SEFT) Terhadap Penanganan Nyeri Dismenorea. Jurnal Kopertis.

Noeng Muhajir. 1991. Metodologi Penelitian Kualitatif. Yogyakarta: Rake Serasih.

Sarlito W Sarwono. 2010. Pengantar Psikologi Umum. Jakarta: PT.Raja Grafindo Persada.

Sarlito Wirawan Sarwono. 2002. Psikologi Remaja. Jakarta: Raja Grafindo Persada. 
Sugiyono. 2005. Memahami

Penelitian Kualitatif. Bandung:

Alfabeta.

Wijiyanti, Fajar. 2010. Efektivitas

Terapi Spiritual Emotional

Freedom Technique (SEFT)

terhadap Penurunan Intensitas

Nyeri pada Pasien Paska-operasi

Sectio Caesaria. Undergraduate thesis. Semarang: Universitas Diponegoro.

Zainuddin A.F. 2009. SEFT For Healing, Success, Happiness, Greatness. Jakarta: Afzan Publishing.

Zainudin, Ahmad Faiz. 2013. SEFTer Handbook Edisi 2 